Review

\title{
Two-Dimensional Transition Metal Carbides and Nitrides (MXenes) for Water Purification and Antibacterial Applications
}

\author{
Inamullah Mahar ${ }^{1, \dagger}{ }^{,}$Fida Hussain Memon ${ }^{2,3,+}$, Jae-Wook Lee ${ }^{3}$, Kyung Hwan Kim ${ }^{3}$, Rafique Ahmed ${ }^{4}$, \\ Faheeda Soomro ${ }^{5}$, Faisal Rehman ${ }^{6} \mathbb{D}$, Ayaz Ali Memon ${ }^{1}$, Khalid Hussain Thebo ${ }^{7, *}$ and Kyung Hyun Choi ${ }^{3, *} \mathbb{D}$ \\ 1 National Centre of Excellence in Analytical Chemistry (NCEAC), University of Sindh, \\ Jamshoro 76060, Sindh, Pakistan; inamullah@gmail.ac.kr (I.M.); ayazmemon33@usindh.edu.pk (A.A.M.) \\ 2 Department of Electrical Engineering, Sukkur IBA University, Sukkur 65200, Sindh, Pakistan; \\ fida.hussain@iba-suk.edu.pk \\ 3 Advanced Micro Mechatronics Lab., Department of Mechatronics Engineering, Jeju National University, \\ Jeju-si 63243, Korea; jaewook482@gmail.com (J.-W.L.); kyunghwankim@jejunu.ac.kr (K.H.K.) \\ 4 Institute of Composite Science Innovation (InCSI), School of Materials Science and Engineering, \\ Zhejiang University, 38 Zheda Road, Hangzhou 310027, China; Rafiqueahmed116@hotmail.com \\ 5 Department of Linguistics and Human Sciences, Begum Nusrat Bhutto Women University, \\ Sukkur 65200, Sindh, Pakistan; faheedasoomro@gmail.com \\ 6 Department of Mechatronics Engineering, College of EME, National University of Sciences and \\ Technology (NUST), Peshawar Road, Rawalpindi 43701, Punjab, Pakistan; \\ Faisal.rehman.be13@iba-suk.edu.pk \\ Citation: Mahar, I.; Memon, F.H.; \\ 7 Institute of Metal Research, Chinese Academy of Sciences (CAS), Shenyang 110016, China \\ * Correspondence: khalidthebo@yahoo.com (K.H.T.); amm@jejunu.ac.kr (K.H.C.) \\ + Authors contributed equally.
} Lee, J.-W.; Kim, K.H.; Ahmed, R.; Soomro, F.; Rehman, F.; Memon, A.A.; Thebo, K.H.; Choi, K.H.

Two-Dimensional Transition Metal Carbides and Nitrides (MXenes) for Water Purification and Antibacterial Applications. Membranes 2021, 11, 869. https://doi.org/10.3390/

membranes11110869

Academic Editors: Olga Arzhakova and Pei Sean Goh

Received: 8 October 2021

Accepted: 5 November 2021

Published: 12 November 2021

Publisher's Note: MDPI stays neutral with regard to jurisdictional claims in published maps and institutional affiliations.

Copyright: (c) 2021 by the authors. Licensee MDPI, Basel, Switzerland. This article is an open access article distributed under the terms and conditions of the Creative Commons Attribution (CC BY) license (https:// creativecommons.org/licenses/by/ $4.0 /)$.
Abstract: Two-dimensional (2D) materials such as graphene, graphene oxide (GO), metal carbides and nitrides (MXenes), transition metal dichalcogenides (TMDS), boron nitride (BN), and layered double hydroxide (LDH) metal-organic frameworks (MOFs) have been widely investigated as potential candidates in various separation applications because of their high mechanical strength, large surface area, ideal chemical and thermal stability, simplicity, ease of functionalization, environmental comparability, and good antibacterial performance. Recently, MXene as a new member of the 2D polymer family has attracted significant attention in water purification, desalination, gas separation, antibacterial, and antifouling applications. Herein, we review the most recent progress in the fabrication, preparation, and modification methods of MXene-based lamellar membranes with the emphasis on applications for water purification and desalination. Moreover, the antibacterial properties of MXene-based membranes show a significant potential for commercial use in water purification. Thus, this review provides a directional guide for future development in this emerging technology.

Keywords: two-dimensional; MXenes; membrane; water purification; antibacterial

\section{Introduction}

The modern world is facing a huge crisis for clean drinking water. Specifically, the populations of underdeveloped and developing countries have been exposed to multiple waterborne fatal diseases, waterborne epidemics, and waterborne insect-based outbreaks [1-6]. Water purification and desalination are considered to be the biggest challenges of this century and various technologies have been developed to fulfil increasing water demands for drinking and agriculture around the world since the 1950s [7-9]. Most were unsuccessful due to high costs, environmental incomparability, a low efficiency and stability, and several fouling issues. Recently, membrane technology has been proven to be versatile for water purification, desalination, and industrial wastewater applications and has significantly improved the quality of life on the planet [10]. Membrane technology possesses a number of advantages such as a reasonable cost, environmental compactness, energy saving, 
simplicity, and good selectivity compared with traditional separation methods including adsorption, absorption, filtration, and distillation [11-13].

Currently, a number of materials such as carbon nanotubes (CNTs), MOFs, COFs, zeolite, polymers, ceramics, graphene, GO, and boron nitride [14-28] have been widely explored in various water purification separation processes. Among them, polymers are commercially used in materials, biomaterials, and membrane technology due to their high packing density, biocompatibility, low cost, and large-scale application in organic and biomedical engineering [29-36]. However, issues such as swelling in organic solvents, fouling in an aqueous medium, and a low stability at high temperatures limit their application [37]. There is a dire need of an alternative polymer material that overcomes the aforementioned limitations.

The recent emergence of 2D MXenes has shown their potential as an ideal material for separation applications owing to their outstanding stability in water, impressive strength, single atomic thickness, good antibacterial properties, high adsorption, and molecular filtration abilities [38-62]. The common formula of MXene is $\mathrm{Mn}_{+1} \mathrm{X}_{n} \mathrm{~T}_{\mathrm{x}}(\mathrm{n}=1-3)$, where $\mathrm{M}$ is the transition metal (i.e., $\mathrm{V}, \mathrm{Mo}, \mathrm{Cr}, \mathrm{Hf}, \mathrm{Zr}, \mathrm{Ta}, \mathrm{Ti}$ ), $\mathrm{X}$ represents carbon and nitrogen atoms, and $\mathrm{Tx}$ stands for the terminated $\mathrm{OH}, \mathrm{O}$, and $\mathrm{F}$ atoms. Due to these surface termination groups, MXene is easily dispersed in water as well as in several organic solvents making it an ideal material for various separation applications in water purification, desalination, organic separation nanofiltration, and biomedical applications. Despite these advantages, only a few MXene members have been explored as separation membranes for water purification and antibacterial studies.

It is necessary to evaluate the current development of MXene-based lamellar membranes for antibacterial and separation utilization. In this short review, the current fabrication and development methods of MXene-based membranes are summarized. MXenebased membranes for desalination, water refinement, and antibacterial applications are discussed in detail. Lastly, this review concludes with several future prospects and recommendations to improve the physicochemical properties of membranes.

\section{Fabrication of MXene-Based Membranes}

MXene (Figure 1a) is a younger member of the 2D family and has been widely fabricated into both laminar as well as pristine nanosheet membranes using different methods. The ideal filtration membranes should be defect free, ultrathin, a dense film and mechanically robust with a high selectivity for small molecules along with good antifouling and antibacterial properties. Generally, methods such as spin coating, spray coating, vacuum filtration, Langmuir-Blodgett, drop casting, or direction evaporation and dip coating are used for the fabrication of 2D MXene lamellar membranes. Gogotsi et al. [63] used a vacuum filtration method for first time to prepare freestanding and PVDF-supported 2D $\mathrm{Ti}_{3} \mathrm{C}_{2} \mathrm{~T}_{\mathrm{x}}$-based membranes. Such membranes demonstrated good hydrophilic properties because of the presence of the useful group in conjunction with excellent elasticity as well as a good mechanical strength, which is an ideal potential in separation membranes. Among these methods, the VF method is widely used for the fabrication of 2D MXene-based membranes due to its simplicity and ease of operation (Figure 1b). Ding et al. [64] also reported 2D MXene $\left(\mathrm{Ti}_{3} \mathrm{C}_{2} \mathrm{~T}_{\mathrm{x}}\right)$ with enhanced properties using a vacuum filtration method on a porous support whereas Kang et al. [65] fabricated MXene $\left(\mathrm{Ti}_{3} \mathrm{C}_{2} \mathrm{~T}_{\mathrm{x}}\right)$ and GO-based composite membranes by the same method. Sun and coworkers also fabricated GO/MXene lamellar membranes by the filtration method [66]. Wang and co-researchers worked out an improvement of the microstructure and physiochemical properties of an MXene membrane by mixing it with a polymer matrix. Recently, Wang et al. [67] reported $\mathrm{Ti}_{3} \mathrm{C}_{2} \mathrm{~T}_{\mathrm{x}}$ lamellar membranes produced by employing a multivalent ion as a hydrogel pillar in the interlayer spacing. Researchers for obtaining the uniform composition mixed a solution of sodium alginate (SA) and MXene $\mathrm{Ti}_{3} \mathrm{C}_{2} \mathrm{~T}_{\mathrm{x}}$; this composite, $\mathrm{SA}-\mathrm{Ti}_{3} \mathrm{C}_{2} \mathrm{~T}_{\mathrm{x}}$, was then used for the lamellar $\mathrm{SA}-\mathrm{Ti}_{3} \mathrm{C}_{2} \mathrm{~T}_{\mathrm{x}}$ membranes. Fascinatingly, a molecule of SA attached onto the MXene sheets by hydrogen bonding and Van der Waals forces. Finally, pillared $S A-\mathrm{Ti}_{3} \mathrm{C}_{2} \mathrm{~T}_{\mathrm{x}}$ laminates 
were arranged by submerging an $\mathrm{SA}-\mathrm{Ti}_{3} \mathrm{C}_{2} \mathrm{Tx}$ membrane into a solution of different types of multivalent cations such as $\mathrm{Ca}^{2+}, \mathrm{Ba}^{2+}, \mathrm{Mn}^{2+}$, and $\mathrm{Al}^{3+}$. The pillar membrane showed a homogeneous structure similar to a nacre-like composite and it considerably decreased the swelling effect. Liu et al. [68] fabricated $\mathrm{Ti}_{3} \mathrm{C}_{2} \mathrm{Tx}-\mathrm{CNT}$ hybrid membranes using vacuum filtration (Figure $1 \mathrm{c}, \mathrm{d}$ ). Liu and coworkers also fabricated pristine $\mathrm{Ti}_{3} \mathrm{C}_{2} \mathrm{Tx}$ and CNT membranes for comparative studies using the VF method (Figure $1 \mathrm{~g}, \mathrm{~h}$ ). They improved the mechanical stability and permeance of MXene by incorporating CNTs into $\mathrm{Ti}_{3} \mathrm{C}_{2} \mathrm{Tx}$ nanosheets. Huang et al. [48] used a phase inversion process to fabricate a PES-Ni@MXene membrane by using an external field and incorporated magnetic Ni@MXene nanoparticles with the upper layer of the PES membrane during a wet phase inversion process. MXenebased lamellar membranes were also prepared by a layer-by-layer (LbL) method [69]. Tian et al. assembled a tris(2-aminoethyl) amine (TAEA) molecule and $\mathrm{Ti}_{3} \mathrm{C}_{2} \mathrm{Tx} \mathrm{MXene}$ using an LbL assembly and obtained highly ordered multilayer of MXene/TAEA with an interlayer distance $\sim 1 \AA$. This strategy was a good addition to fabricate MXene-based multilayered membranes for large-scale applications.
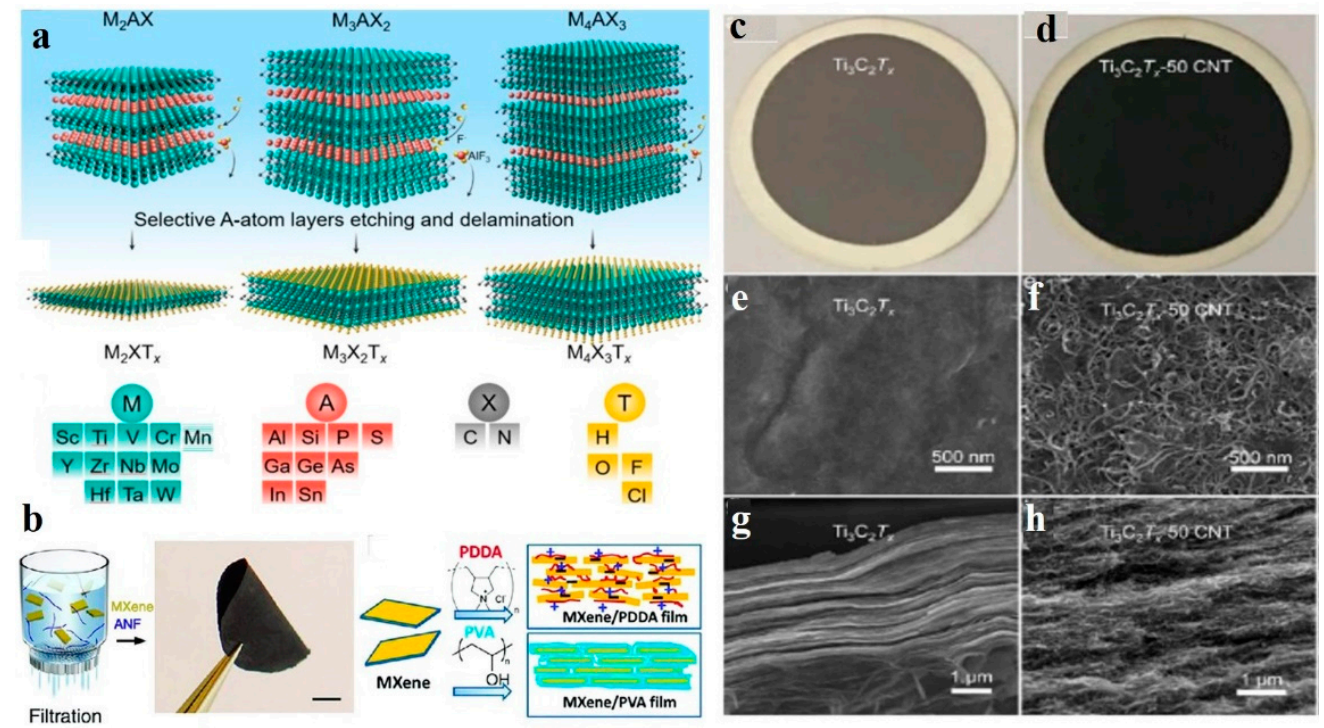

Figure 1. (a) MXene precursors and their common synthesis methods. Reprinted with permission from [70]. Copyright 2020 Springer Nature Group. (b) Fabrication of MXene/polymer-based composite membrane by the VF method. Reprinted with permission from [63]. Copyright 2015 American Chemical Society. (c,d) Fabrication of pristine $\mathrm{Ti}_{3} \mathrm{C}_{2} \mathrm{Tx}_{\mathrm{and}} \mathrm{Ti}_{3} \mathrm{C}_{2} \mathrm{Tx}-\mathrm{CNT}$ composite membranes. (e) The digital photograph of the solutions. (f) AFM study of $\mathrm{Ti}_{3} \mathrm{C}_{2} \mathrm{Tx}$ nanosheets. (g,h) Digital photos: surface; cross-sectional SEM images of pristine $\mathrm{Ti}_{3} \mathrm{C}_{2} \mathrm{Tx}, \mathrm{Ti}_{3} \mathrm{C}_{2} \mathrm{Tx}-\mathrm{CNT}$, and CNT membranes, respectively. Reprinted with permission from [68]. Copyright 2020 American Chemical Society.

From the above studies, it was concluded that the vacuum filtration method was mostly used to fabricate MXene membranes. However, there are several disadvantages associated with the vacuum filtration method. It needs a large volume of solvent, takes long time, and is definitely difficult to scale up. Therefore, alternative methods such as the shear alignment method, printing method, and spin coating method should be utilized to fabricate state-of-the-art MXene-based laminar membranes with advanced physicochemical properties to fully utilize the power of this wonder material.

\section{Water Purification and Desalination Applications}

Water pollution and desalination are the most important issues in recent days, which greatly affect the quality of life on earth. The commercially used membranes for water purification and desalination are suppressed by antifouling problems that decrease the life of the membrane and increase the operational cost. Therefore, researchers focus on introducing novel materials to enhance the antifouling property of the membrane to save 
energy and the operational cost. Recently, MXene-based membranes have been widely used for wastewater treatment, water purification, and desalination applications, as shown in Table 1 [71-82]. Initial work by Gogotsi et al. [63] demonstrated 2D MXene-based membranes with PVDF supported particular ion separations; for instance, $\mathrm{Mg}^{2+}, \mathrm{Ca}^{2+}$, $\mathrm{Li}^{+}, \mathrm{Al}^{3+}, \mathrm{Ni}^{2+}, \mathrm{Na}^{+}$, and $\mathrm{K}^{+}$. The fabricated membrane exhibited a good permeability of $\sim 37.4 \mathrm{~L} \mathrm{~m}^{-2} \mathrm{~h}^{-1} \mathrm{bar}^{-1}$. Metal ions having lesser hydration radii and a larger charge than the space between the MXene interlayers $\left(\sim 6 \mathrm{~A}^{\circ}\right)$ indicated a slow permeability compared with single-charged cations. Such membranes have been inspected for antibacterial and biofouling properties of a single and a few layers of $\mathrm{Ti}_{3} \mathrm{C}_{2} \mathrm{~T}_{\mathrm{x}}$ MXene flakes in a colloidal solution. Liu et al. [83] produced a $\mathrm{Ti}_{3} \mathrm{C}_{2} \mathrm{~T}_{\mathrm{x}}$ membrane on polyacrylonitrile for $\mathrm{NaCl}$ salt separation. A 60 nm-thick membrane exhibited $99.5 \%$ separation efficiency and water permeance up to $\sim 85 \mathrm{~L} \mathrm{~m}^{-2} \mathrm{~h}^{-1} \mathrm{bar}^{-1}$ at $65{ }^{\circ} \mathrm{C}$. Mahmoud et al. [84] boosted the antifouling properties, water permeance, and rejection through an MXene/Ag composite; the fabricated composite was $470 \mathrm{~nm}$ of thickness with $21 \%$ loading of AgNPs. Compared with pristine MXene laminates $\left(\sim 118 \mathrm{~L} \mathrm{~m}^{-2} \mathrm{~h}^{-1} \mathrm{bar}^{-1}\right)$, the prepared composite membrane showed $\sim 420 \mathrm{~L} \mathrm{~m}^{-2} \mathrm{~h}^{-1}$ bar $^{-1}$ water permeance under the same condition. This membrane also proved to have the highest stability in synthetic sea water. Lu et al. [85] validated a self-crosslinked MXene membrane (SCMMs) for the monovalent separation of ions. The terminal functional groups of MXene nanosheets were crosslinked with each other through a self-crosslinking reaction $\left(-\mathrm{H}+-\mathrm{OH}=-\mathrm{O}-+\mathrm{H}_{2} \mathrm{O}\right)$. By this approach, the swelling of MXene decreased up to $15.4 \AA$ compared with a pristine MXene membrane $(16.6 \AA)$ and showed outstanding constancy for $70 \mathrm{~h}$. The permeation rate of SCMMs was near to two orders of magnitude less than the pristine MXene membrane, which specified the noticeably better enactment of the ion segregation by self-crosslinking between the MXene nanosheets. These membranes also indicated comparatively few monovalent ion permeation rates where the rates of permeation for $\mathrm{Li}^{+}$(hydrated diameter of $7.65 \AA$ ), $\mathrm{Na}^{+}$(hydrated diameter of $7.16 \AA$ ), and $\mathrm{K}^{+}$(hydrated diameter $6.62 \AA$ ) were $0.0283,0.222$, and $0.232 \mathrm{~mol} \mathrm{~h}^{-1} \mathrm{~m}^{-2}$, respectively. Similar to other 2D materials, MXene also has a water swelling property and delaminates easily because of hydrogen bonding and electrostatics, that affect the separation efficiency of the membranes. Wang et al. [67] arranged pillared lamellar membranes (M-SAT) with improved separation properties. Metal cations such as $\mathrm{Mn}^{2+}$ and $\mathrm{Ca}^{2+}$ enlarged the d-spacing from 13.8 to $15.2 \AA$ of a pristine $\mathrm{Ti}_{3} \mathrm{C}_{2} \mathrm{~T}_{\mathrm{x}}$ membrane. These metal cations were presented as a support between the MXene nanosheets. An improvement in the selectivity of the 2D laminates highly depended upon the d-spacing. An ultrathin M-SAT pillared membrane expressed $100 \%$ rejection of $\mathrm{Na}_{2} \mathrm{SO}_{4}$ salt with an improvement in the d-spacing. As associated to the earlier reported MXene-based membrane, this showed less swelling. Ding et al. [86] developed non-swelling MXene laminates for water cleansing with enriched separation properties (Figure 2a,b) by inserting $\mathrm{Al}^{3+}$ ions between MXene nanosheets (Figure 2a). These ions produced a strong electrostatic interaction with the functional groups of MXene. In the end, the membranes exhibited less swelling in the water and the stability was increased for up to $400 \mathrm{~h}$. Moreover, these laminates presented $89.5-99.5 \%$ rejection against $\mathrm{NaCl}$ with better water permeance of 1.1-8.5 $\mathrm{Lm}^{-2} \mathrm{~h}^{-1}$ bar $^{1}$, as shown in Figure $2 \mathrm{c}-\mathrm{f}$. 


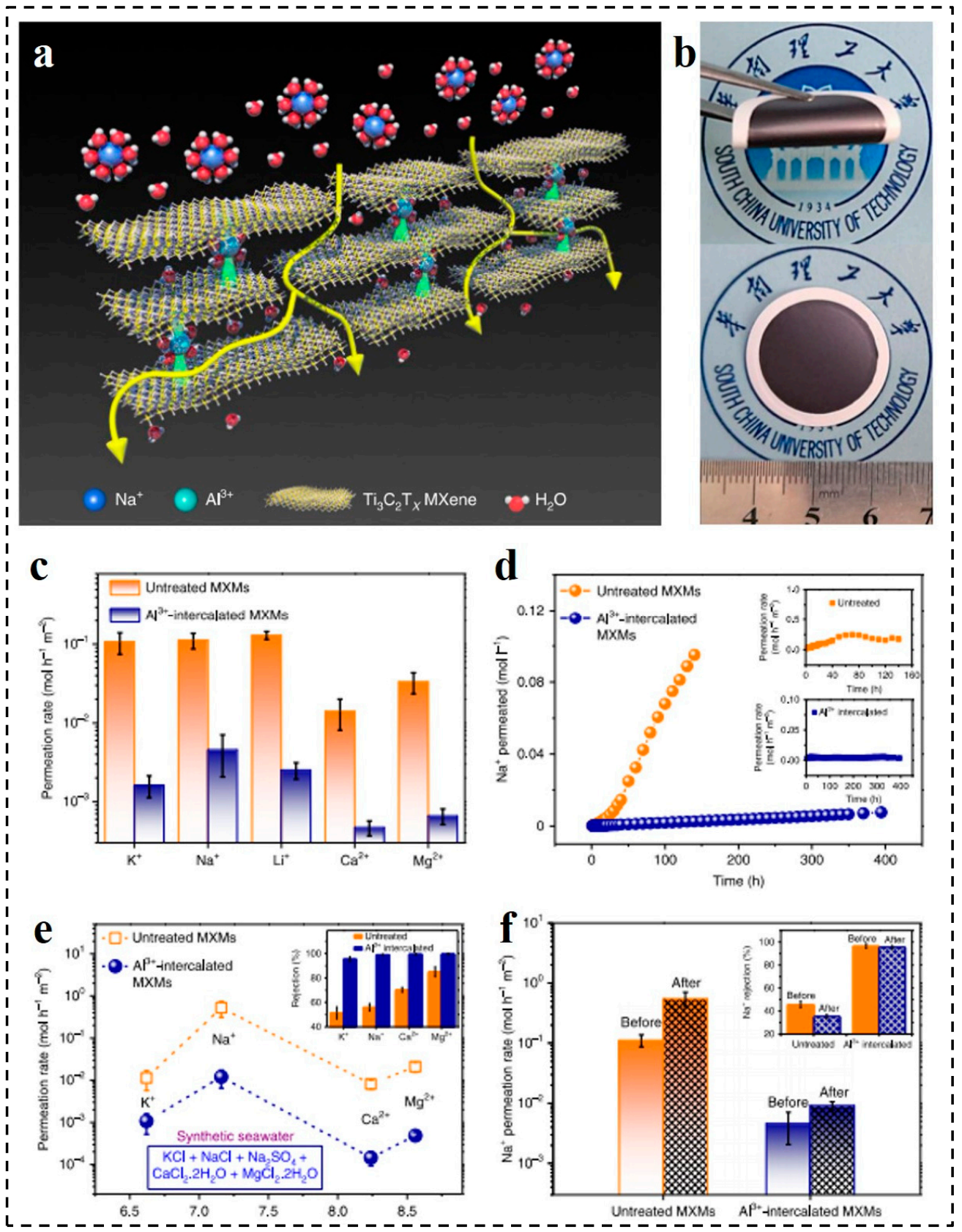

Figure 2. $\mathrm{Ti}_{3} \mathrm{C}_{2} \mathrm{Tx}$ MXene membranes (MXM): (a) Schematic representation of $\mathrm{Al}^{3+}$ intercalation between two adjacent MXene layers and thus a fixed d-spacing. The hydrated cation such as $\mathrm{Na}+$ are rejected and the water molecules can permeate through the MXM. (b) Digital photos of untreated MXM and its blending state. (c-f) The ion permeation rate and DI permeance (c); time-dependent $\mathrm{Na}^{+}$permeation (d); comparison of the rates of ions in synthetic seawater (e); chlorine resistance (f); of untreated MXMs and $\mathrm{Al}^{3+}$-intercalated MXMs. Reprinted with permission from [86]. Copyright 2020 Nature Publishing Group.

As for molecular separation, Wang et al. [87] demonstrated a novel type of $2 \mathrm{D} g-\mathrm{C}_{3} \mathrm{~N}_{4}$ nanosheet membrane with artificial nanopores for water purification. These nanosheet membranes were exploited for the removal of distinct types of molecules, for example, Evan blue (EB), rhodamine B (RB), gold nanoparticles (Au NPs), and cytochrome C (Cytc), as shown in Figure 3a,b. The rejection percentages of $87.2 \%, 75.5 \%, 99.5 \%$, and 93.1\% for EB, RB, Au NPs, and Cytc were obtained, respectively. The 160 nm-thick membrane 
showed water permeance up to $\sim 29 \mathrm{~L} \mathrm{~m}^{-2} \mathrm{~h}^{-1} \mathrm{bar}^{-1}$. Additionally, the permeability of the membranes against variable thicknesses and pressures was also validated (Figure $3 c, d$ ).
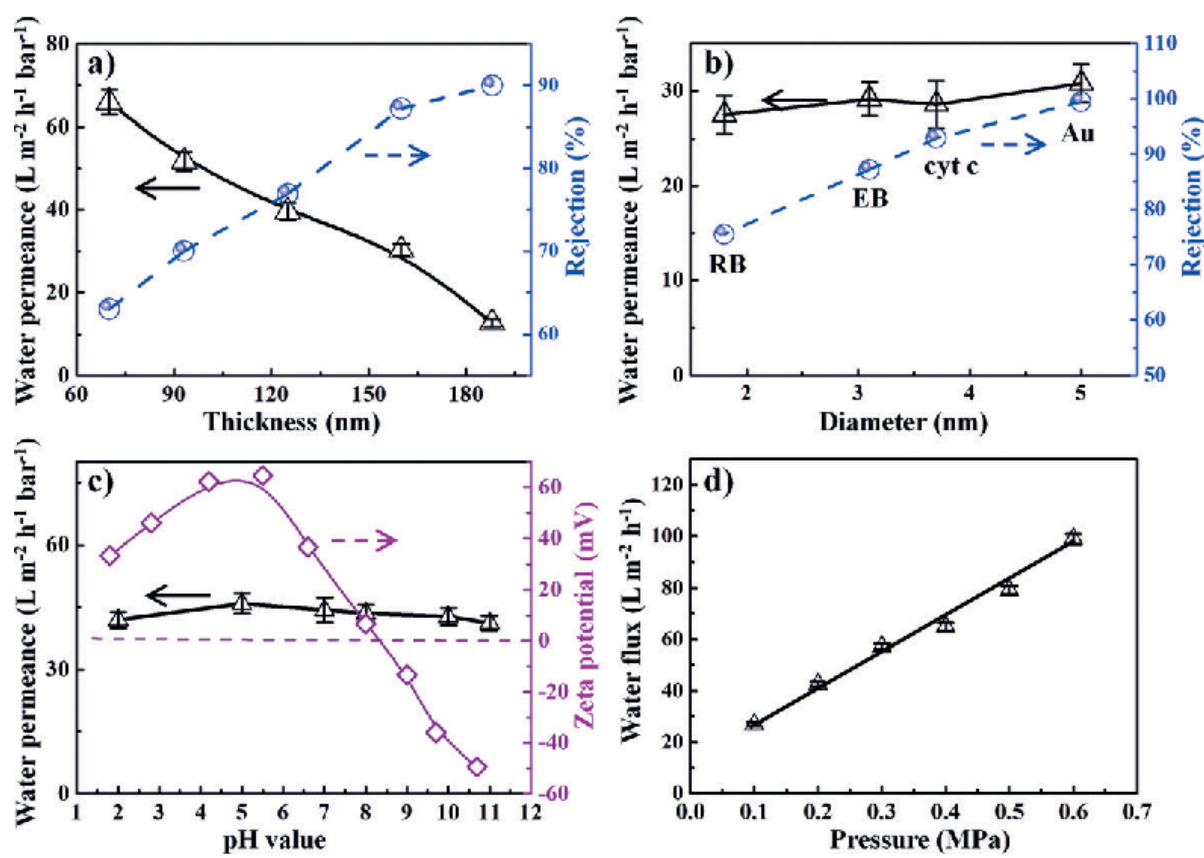

Figure 3. MXene-based ( $\mathrm{g}-\mathrm{C}_{3} \mathrm{~N}_{4}$ ) nanosheet membranes for dye separation: $\mathrm{g}-\mathrm{C}_{3} \mathrm{~N}_{4}$ nanosheet membranes; separation performance of $\mathrm{g}-\mathrm{C}_{3} \mathrm{~N}_{4}$ membranes against different dye molecules. (a) Separation performance based on the thickness of the membranes; (b) against the diameter (size) of each probe molecule; (c) water permeance and zeta potential of the membrane in different $\mathrm{pH}$ environments; (d) water permeability based on variable pressure. Reprinted with permission from [87]. Copyright 2020 American Chemical Society.

Han et al. [88] demonstrated PES/MXene ultrafiltration membranes for the separation of Congo red (CR) dye. The as-prepared membrane showed pure water permeance of $\sim 115 \mathrm{Lm}^{-2} \mathrm{~h}^{-1}$ and a $92.3 \%$ rejection of the CR dye at $0.1 \mathrm{MPa}$. Kang and coworkers fabricated a $\mathrm{Ti}_{3} \mathrm{C}_{2} \mathrm{Tx} / \mathrm{GO}$ composite membrane with a thickness of $90 \mathrm{~nm}$, as shown in Figure 4a [65]. The interlayer of the as-prepared membrane was around $5 \AA$ due to swelling in the water. Such membranes showed $>99 \%$ for those molecules, which had radii greater than $5 \AA$ at a pressure of 5 bar and obtained $68 \%, 99.5 \%, 93.5 \%$, and $100 \%$ rejection of methyl blue (MB, hydrated radii 4.87), methylene blue (MLB, 5.04), rose Bengal (RB, 5.88), and brilliant blue (BB, 7.98), respectively (Figure 4b,c). Recently, Liu et al. [66] also fabricated an MXene/GO membrane and used it for the separation of small organic dyes such as NR, MB, CV, and BB. The membrane showed a $>99 \%$ rejection of these dyes. Similar membranes also showed an excellent rejection of bovine serum albumin (BSA) and humic acid (HA) molecules. However, these membrane showed less permeability compared with previously reported MXene/GO membranes [65]. Various studies have shown that $\mathrm{pH}$, temperature, pressure, and water uptake significantly affect the microstructural properties and separation performance of $2 \mathrm{D}$ membranes. Ding and coworkers used a VF technique to develop a $2 \mathrm{D} \mathrm{Ti}_{3} \mathrm{C}_{2} \mathrm{~T}_{\mathrm{x}}$-based novel membrane on an AAO support [64]. The as-prepared membranes showed outstanding water permeability for DI water up to $\sim 1000 \mathrm{Lm}^{-2} \mathrm{~h}^{-1} \mathrm{bar}^{1}$. Furthermore, the separation effectiveness of laminates with different sizes of molecules was estimated by Ding et al. [64]. For molecules having a diameter larger than $2.5 \mathrm{~nm}$, the membrane showed more than a 90\% rejection rate. Ma et al. [89] fabricated a P84-copolyimide/MXene-based membrane with an excellent water permeability of $\sim 268 \mathrm{~L} \mathrm{~m}^{-2} \mathrm{~h}^{-1} \mathrm{bar}^{-1}$ at $0.1 \mathrm{MPa}$ and ensured a $99 \%$ rejection of gentian violet dye. Shen et al. [77] reported MXene/PSF $\left(\mathrm{Ti}_{3} \mathrm{C}_{2} \mathrm{Tx}\right)$ membranes with a $99 \%$ rejection of a BSA molecule and water permeance up to $\sim 218 \mathrm{Lm}^{-2} \mathrm{~h}^{-1} \mathrm{bar}^{-1}$. Recently, Liu and 
coworkers demonstrated a $\mathrm{Ti}_{3} \mathrm{C}_{2} \mathrm{Tx} / \mathrm{CNT}$ hybrid membrane for the recovery of precious metals, i.e., gold (Au) [68]. The as-prepared membranes showed an excellent ability to capture $\mathrm{Au}$ (III) up to $99.8 \%$ and the water permeance reached up to $\sim 437.6 \mathrm{Lm}^{-2} \mathrm{~h}^{-1} \mathrm{bar}^{-1}$, approximately 202 times higher than the pristine MXene membrane reported.

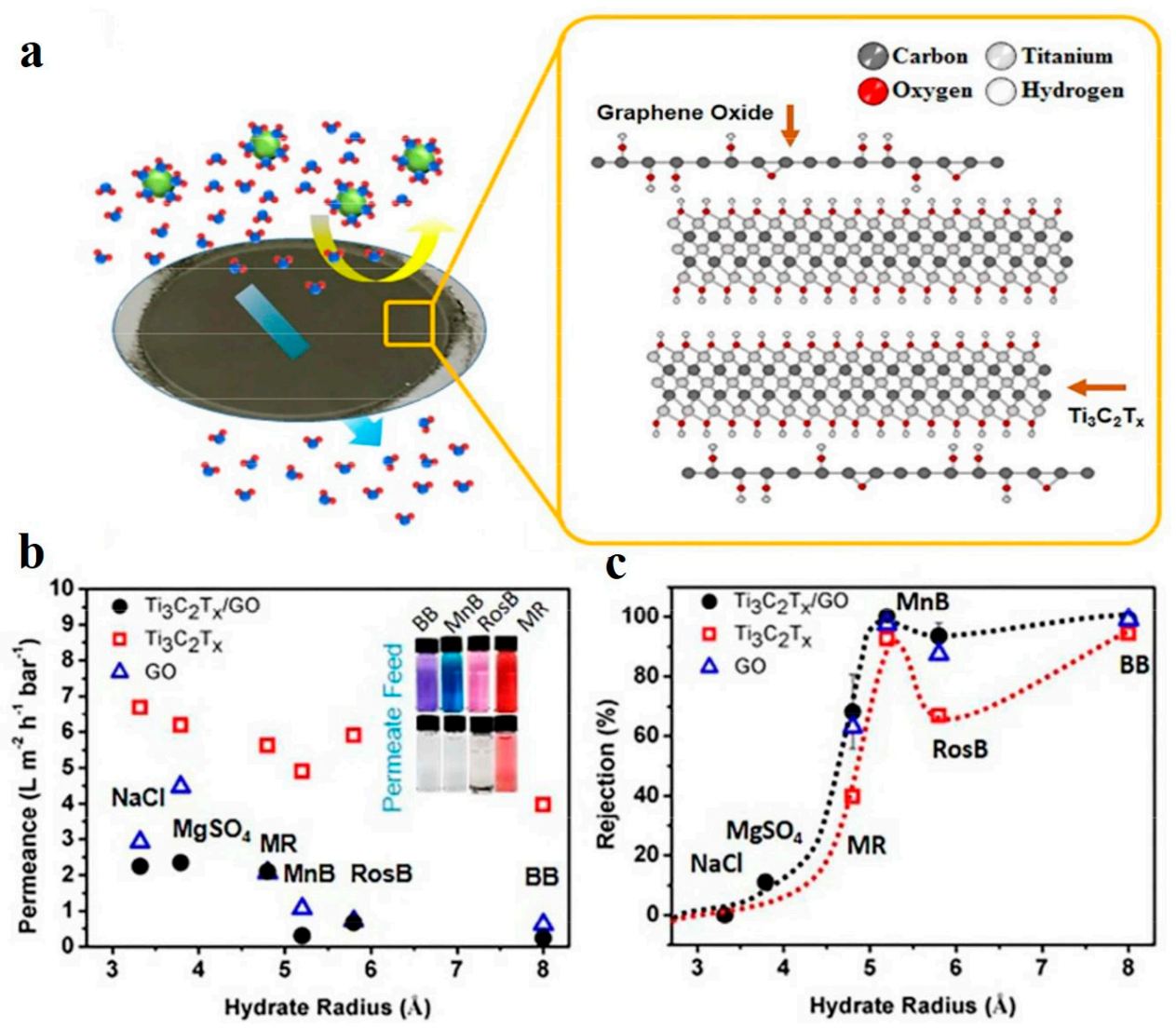

Figure 4. (a) Digital photograph of an MXene $\left(\mathrm{Ti}_{3} \mathrm{C}_{2} \mathrm{~T}_{X}\right) / \mathrm{GO}$-based composite membrane for water purification and a schematic representation of an ionic and molecular sieving mechanism. (b) Separation efficiency of various probe molecules with different sizes through a $90 \mathrm{~nm}$-thick $\mathrm{Ti}_{3} \mathrm{C}_{2} \mathrm{~T}_{\mathrm{x}} / \mathrm{GO}$ composite membrane before and after filtration. (c) The separation performance of a pristine GO, MXene, and MXene/GO composite membrane against different probe molecules. Reprinted with permission from [65]. Copyright 2017 American Chemical Society.

Many works have described MXene-based lamellar membranes for desalination and water purification. Most of the MXene laminates were arranged on a polymeric substrate for superior performance and rejection. MXenes also have a weak bond with substrates; the resulting membranes can be easily destroyed and this greatly affects the separation performance of the membranes. As with GO laminates, MXene has also showed a good water permeance due to its hydrophilic nature. MXene-based membranes allowed cations with a larger hydration radii than the interlayer space between the MXene interlayers $(0.6 \mathrm{~nm})$. Furthermore, if the cations showed a greater charge, the membrane performed a slow permeation compared with the single-charged cations. Hence, the physicochemical and separation properties of MXene-based membranes can be improved by using suitable intercalation or crosslinking to control the pore structure. Further 2D-2D intercalations can also improve the permeance and selectivity of the membranes.

\section{Antibacterial Activity of MXene-Based Membranes}

Pathogenic contamination is considered to be the most harmful issue worldwide and is responsible for various kinds of waterborne diseases [90]. It is directly responsible for the biofouling of any water filtration membrane; therefore, it is important that a membrane should be tested against antibacterial properties. Up to date, several bactericidal 
nanomaterials including graphene, TMDCs, and MXenes have been explored to meet these challenges. The antibacterial activity of graphite, graphite oxide, GO, $\mathrm{rGO}, \mathrm{MoS}_{2}$, and $\mathrm{WS}_{2}$ against Gram-negative and Gram-positive bacteria have already been tested. Recently, MXenes with unique hydrophilic properties, a good adsorption, an ideal surface functionality, and excellent biocompatibility and photothermal properties have been widely tested for wastewater treatment and desalination, water purification, ion separation and other applications, as shown in Table 1. MXenes are expected to be resistant to biofouling and offer bactericidal properties [91]. However, very few studies [91-99] have been carried out in this direction. An initial work by Rasool et al. [97] reported that $\mathrm{Ti}_{3} \mathrm{C}_{2} \mathrm{Tx}$ membranes could be an ideal platform for antibacterial studies (Figure 5a-d). Rasool et al. [97] further used $\mathrm{Ti}_{3} \mathrm{C}_{2} \mathrm{~T}_{\mathrm{x}}$-based membranes to measure the antibacterial properties against Escherichia coli (E. coli) and Bacillus subtilis (B. subtilis) by using bacterial growth curves based on optical densities (OD) and colony growth on agar nutritive plates (Figure $5 b, c)$. The membranes showed a high antibacterial efficiency against both Gram-negative E. coli and Gram-positive B. subtilis compared with the GO membranes. Concentration-dependent antibacterial activity was observed and more than $98 \%$ of bacterial cell viability loss was found at $200 \mu \mathrm{g} / \mathrm{mL}$ in $\mathrm{Ti}_{3} \mathrm{C}_{2} \mathrm{~T}_{\mathrm{x}}$ for both bacterial cells within $4 \mathrm{~h}$ of exposure, as confirmed by a colony-forming unit (CFU) and regrowth curve (Figure 5d,e). In another study, $\mathrm{Ti}_{3} \mathrm{C}_{2} \mathrm{~T}_{\mathrm{x}} /$ PVDF composite membranes were tested to measure the antibacterial rate of E. coli and B. subtilis [91]. The composite membranes showed a $\sim 73 \%$ and $\sim 63 \%$ antibacterial rate for $B$. subtilis and E. coli, respectively, compared with the control PVDF membranes [91]. Additionally, the $\mathrm{Ti}_{3} \mathrm{C}_{2} \mathrm{~T}_{\mathrm{x}}$ membrane showed over a $99 \%$ growth inhibition of both bacteria under the same conditions. Mayerberger et al. [92] demonstrated $\mathrm{Ti}_{3} \mathrm{C}_{2} \mathrm{Tz} /$ chitosan composite nanofiber membranes for a passive antibacterial wound dressing application. The as-prepared composite membrane showed a $95 \%$ and $62 \%$ reduction in the colony-forming units of Gram-negative E. coli and Gram-positive Staphylococcus aureus (S. aureus), respectively. Jastrzebsa and coworkers also reported the antimicrobial properties of a $\mathrm{Ti}_{3} \mathrm{C}_{2} \mathrm{MXene-based} \mathrm{nanocomposite,} \mathrm{i.e.,} \mathrm{Ti}_{3} \mathrm{C}_{2} / \mathrm{SiO}_{2} / \mathrm{Ag}, \mathrm{Ti}_{3} \mathrm{C}_{2} / \mathrm{Al}_{2} \mathrm{O}_{3} / \mathrm{Ag}$, and $\mathrm{Ti}_{3} \mathrm{C}_{2} / \mathrm{SiO}_{2} / \mathrm{Pd}$ [93]. They also demonstrated the outstanding bioactive properties of $\mathrm{Ti}_{2} \mathrm{C}$ and $\mathrm{Ti}_{3} \mathrm{C}_{2}$ MXenes against a Gram-negative bacterial strain [99]. Recently, Zhu et al. [95] evaluated the effect of near-infrared (NIR) light on the antibacterial activities of silver (Ag), $\mathrm{Ti}_{3} \mathrm{C}_{2} \mathrm{~T}_{x}$, and an $\mathrm{Ag} / \mathrm{Ti}_{3} \mathrm{C}_{2} \mathrm{~T}_{x}$ composite. The as-prepared $\mathrm{Ag} / \mathrm{Ti}_{3} \mathrm{C}_{2} \mathrm{~T}_{x}$ composite showed a high efficacy against Gram-positive $S$. aureus and Gram-negative E. coli bacteria in an in vitro antibacterial test. Upon NIR irradiation, the antimicrobial effect of $\mathrm{Ag} / \mathrm{Ti}_{3} \mathrm{C}_{2} \mathrm{~T}_{x}$ significantly strengthened compared with the pristine $\mathrm{Ag}$ and $\mathrm{Ti}_{3} \mathrm{C}_{2} \mathrm{~T}_{\mathrm{x}}$. The growth of $E$. coli was completely inhibited during the initial $0-6 \mathrm{~h}$ by $200 \mu \mathrm{g} / \mathrm{mL}$ of $\mathrm{Ti}_{3} \mathrm{C}_{2} \mathrm{~T}_{\mathrm{x}}$ due to the photothermal heat produced killing the bacteria in the surrounding area. The $\mathrm{Ag} / \mathrm{Ti}_{3} \mathrm{C}_{2} \mathrm{~T}_{\mathrm{x}}$ composite exhibited the best antibacterial activities with the same dose of pristine $\mathrm{Ag}$ and $\mathrm{Ti}_{3} \mathrm{C}_{2} \mathrm{~T}_{\mathrm{x}}$. After NIR irradiation, the $\mathrm{Ti}_{3} \mathrm{C}_{2} \mathrm{~T}_{\mathrm{x}}$ composite could completely restrain the E. coli growth when used at 100-200 $\mu \mathrm{g} / \mathrm{mL}$. 



Figure 5. $\mathrm{Ti}_{3} \mathrm{C}_{2} \mathrm{~T}_{\mathrm{x}}$ nanosheet membranes. (a) Antibacterial activities of $\mathrm{Ti}_{3} \mathrm{C}_{2} \mathrm{~T}_{\mathrm{x}}$ membranes in an aqueous solution against $E$. coli and (b) B. subtilis with different concentrations, i.e., $0 \mu \mathrm{g} / \mathrm{mL}$ (A), $10 \mu \mathrm{g} / \mathrm{mL}$ (B), $20 \mu \mathrm{g} / \mathrm{mL}$ (C), $50 \mu \mathrm{g} / \mathrm{mL}$ (D), $100 \mu \mathrm{g} / \mathrm{mL}$ (E), and $200 \mu \mathrm{g} / \mathrm{mL}$ (F), respectively. (c,d) Cell viability measurement and comparison studies of $\mathrm{Ti}_{3} \mathrm{C}_{2} \mathrm{~T}_{\mathrm{x}}$ and $\mathrm{GO}$ membranes against E. coli and B. subtilis bacterial strains. Bacterial suspensions (107 CFU/mL) were incubated with different concentrations $(0-200 \mu \mathrm{g} / \mathrm{mL})$ of $\mathrm{Ti}_{3} \mathrm{C}_{2} \mathrm{~T}_{\mathrm{x}}$ and GO membranes at $35^{\circ} \mathrm{C}$ for $4 \mathrm{~h}$ at a speed of $150 \mathrm{rmp}$. Reprinted with permission from [97]. Copyright 2016 American Chemical Society.

Table 1. MXene-based membranes for the separation of ions, molecules, and pathogens from water.

\begin{tabular}{|c|c|c|c|c|c|}
\hline Type of Membrane & Fabrication Method & Feed Solution/Concentration & Rejection (\%) & $\begin{array}{c}\text { Permeability } \\
\left(\mathrm{Lm}^{-2} \mathrm{~h}^{-1} \text { bar }^{-1}\right)\end{array}$ & Ref. \\
\hline \multirow{3}{*}{$\mathrm{Ti}_{3} \mathrm{C}_{2} \mathrm{Tx}$} & \multirow{3}{*}{ Vacuum filtration } & $\mathrm{RB}$ & 85 & \multirow{3}{*}{1084} & \multirow{3}{*}{ [64] } \\
\hline & & EB & 90 & & \\
\hline & & $\begin{array}{c}\mathrm{CC} \\
(\text { Each } 10-20 \mathrm{mg} / \mathrm{L})\end{array}$ & 97 & & \\
\hline \multirow{2}{*}{$\mathrm{Ti}_{3} \mathrm{C}_{2} \mathrm{Tx}$} & \multirow{2}{*}{ Vacuum filtration } & $\begin{array}{c}\mathrm{NaCl} \\
(10,000 \mathrm{mg} / \mathrm{L})\end{array}$ & \multirow{2}{*}{$56-64$} & \multirow{2}{*}{10} & \multirow{2}{*}{ [100] } \\
\hline & & $\begin{array}{c}\text { BSA } \\
(2000 \mathrm{mg} / \mathrm{L})\end{array}$ & & & \\
\hline \multirow{5}{*}{$\mathrm{Ti}_{3} \mathrm{C}_{2} \mathrm{Tx}$} & \multirow{5}{*}{ Vacuum filtration } & $\mathrm{CR}$ & 92 & \multirow{5}{*}{405} & \multirow{5}{*}{ [74] } \\
\hline & & GN & 80 & & \\
\hline & & $\mathrm{MgCl} 2$ & 2.3 & & \\
\hline & & $\mathrm{Na} 2 \mathrm{SO} 4$ & 13.2 & & \\
\hline & & $\begin{array}{c}\mathrm{NaCl} \\
\text { (Each 100-1000 mg/L) }\end{array}$ & $13.8 \%$ & & \\
\hline \multirow{2}{*}{$\mathrm{Ti}_{3} \mathrm{C}_{2} \mathrm{Tx}$} & \multirow{2}{*}{ Vacuum filtration } & E. coli & $>99$ & \multirow{2}{*}{37.4} & \multirow{2}{*}{ [91] } \\
\hline & & B. subtilis & $>99$ & & \\
\hline
\end{tabular}


Table 1. Cont.

\begin{tabular}{|c|c|c|c|c|c|}
\hline Type of Membrane & Fabrication Method & Feed Solution/Concentration & Rejection (\%) & $\begin{array}{c}\text { Permeability } \\
\left(\mathrm{Lm}^{-2} \mathrm{~h}^{-1} \text { bar }^{-1}\right)\end{array}$ & Ref. \\
\hline \multirow{5}{*}{$\mathrm{Ti}_{3} \mathrm{C}_{2} \mathrm{Tx}$} & \multirow{5}{*}{ Vacuum filtration } & $\mathrm{Na}_{2} \mathrm{SO}_{4}$ & \multirow{5}{*}{$50-99$} & \multirow{5}{*}{$5-15.25$} & \multirow{5}{*}{ [101] } \\
\hline & & $\mathrm{Mg}_{2} \mathrm{SO}_{4}$ & & & \\
\hline & & $\mathrm{MgCl}_{2}$ & & & \\
\hline & & $\mathrm{NaCl}$ & & & \\
\hline & & $\mathrm{VOSO}_{4}$ & & & \\
\hline \multirow{3}{*}{$\mathrm{Ti}_{3} \mathrm{C}_{2} \mathrm{Tx}-\mathrm{Ag}$} & \multirow{3}{*}{$\begin{array}{l}\text { Vacuum-assisted } \\
\text { filtration }\end{array}$} & $\mathrm{RB}$ & 79.9 & \multirow{3}{*}{$\sim 420$} & \multirow{3}{*}{ [84] } \\
\hline & & MG & 92.3 & & \\
\hline & & $\begin{array}{c}\text { BSA } \\
(50-100 \mathrm{mg} / \mathrm{L})\end{array}$ & $>99 \%$ & & \\
\hline \multirow{6}{*}{$\mathrm{Ti}_{3} \mathrm{C}_{2} \mathrm{Tx}-\mathrm{GO}$} & \multirow{6}{*}{ Vacuum filtration } & BB & 95.4 & \multirow{6}{*}{$\sim 25 \mathrm{~L}$} & \multirow{6}{*}[65]{} \\
\hline & & Rose Bengal & 94.6 & & \\
\hline & & MLB & 40 & & \\
\hline & & MLR & 5 & & \\
\hline & & $\mathrm{MgSO} 4$ & \multirow{2}{*}{$<1$} & & \\
\hline & & $\begin{array}{c}\mathrm{NaCl} \\
(\text { Each } 10 \mathrm{mg} / \mathrm{L})\end{array}$ & & & \\
\hline \multirow{6}{*}{$\mathrm{Ti}_{3} \mathrm{C}_{2} \mathrm{Tx}-\mathrm{GO}$} & \multirow{6}{*}{ Vacuum filtration } & $\mathrm{RB}$ & \multirow{4}{*}{$>97$ (dyes) } & \multirow{6}{*}{89.6} & \multirow{6}{*}{ [102] } \\
\hline & & MB & & & \\
\hline & & $\mathrm{CV}$ & & & \\
\hline & & $\begin{array}{c}\text { NR } \\
(\text { Each } 10 \mathrm{mg} / \mathrm{L})\end{array}$ & & & \\
\hline & & $\mathrm{Na}_{2} \mathrm{SO}_{4}$ & 61 & & \\
\hline & & $\begin{array}{c}\mathrm{NaCl} \\
\text { (Each } 5 \mathrm{mM} \text { ) }\end{array}$ & 23 & & \\
\hline \multirow{9}{*}{$\mathrm{Ti}_{3} \mathrm{C}_{2} \mathrm{Tx}-\mathrm{GO}$} & \multirow{9}{*}{ Vacuum filtration } & Chrysoidine G & \multirow{7}{*}{ >99\% (dyes) } & \multirow{9}{*}{71.9} & \multirow{9}{*}{ [80] } \\
\hline & & MLB & & & \\
\hline & & NR & & & \\
\hline & & $\mathrm{CV}$ & & & \\
\hline & & BB & & & \\
\hline & & HA & & & \\
\hline & & BSA & & & \\
\hline & & $\mathrm{Na}_{2} \mathrm{SO}_{4}$ & 61 & & \\
\hline & & $\begin{array}{c}\mathrm{NaCl} \\
(\text { Each } 10 \mathrm{mg} / \mathrm{L})\end{array}$ & 23 & & \\
\hline \multirow{5}{*}{$\mathrm{Ti}_{3} \mathrm{C}_{2} \mathrm{Tx}-\mathrm{GO}$} & \multirow{5}{*}{ Vacuum filtration } & $\mathrm{MO}$ & \multirow{5}{*}{$>95$} & \multirow{5}{*}{$\sim 8.5-11$} & \\
\hline & & MLB & & & \\
\hline & & Acid yellow 14 & & & [101] \\
\hline & & IC & & & \\
\hline & & $\begin{array}{c}\text { Eosin } \\
\text { (Each } 10 \mathrm{mg} / \mathrm{L})\end{array}$ & & & \\
\hline $\mathrm{Ti}_{3} \mathrm{C}_{2} \mathrm{Tx}-\mathrm{TiO}_{2}$ & Spin coating & $\begin{array}{c}\text { Dextran } \\
(3000 \mathrm{mg} / \mathrm{L})\end{array}$ & $>95$ & $\sim 90$ & [103] \\
\hline
\end{tabular}

CC: cytochrome C; MLB: methylene blue; RB: rhodamine B; EB: Evan blue; MO: methyl orange; IC: indigo carmine; HA: humic acid; BB: brilliant blue; NR: neutral red; CV: crystal violet; CR: Congo red; GN: gentian violet; MG: methyl green; MLR: methylene red. 


\section{Conclusions and Future Perspectives}

Since the discovery of MXene, it has been widely investigated for various applications; however, less work has been done on MXene-based membranes for water purification, desalination, and antibacterial applications [104,105]. In this review, we have summarized the recent progress of MXene-based membranes for water purification and antibacterial applications from both a theoretical and an experimental point of view. Different fabrication and modification methods for MXene laminates have been highlighted. The current challenge is the scalable production of MXenes because these preparation methods are expensive with a time-consuming synthesis, low yield, purity, and can be environmentally incompatible.

Most of existing studies were limited to a specific MXene, i.e., $\mathrm{Ti}_{3} \mathrm{C}_{2} \mathrm{~T}_{\mathrm{x}}$. Therefore, other members of same family need to be explored to fully utilize their power in separation applications. In addition, MXene-based membranes are only used for particular types of dye molecules and ions. The separation of small molecules (dyes or ions) that have a diameter less than $5 \AA$ is still a big challenge for MXenes. Moreover, MXene-based membranes are still absent in other separation applications such as electrodialysis, organic separation nanofiltration, and forward osmosis. In term of selectivity, permeance, and separation applications, MXene is far behind graphene. Therefore, MXene needs to be explored for novel types of separation in future and to improve its permeance and selectivity.

The stability of MXene in water-based applications is another key issue; it can easily be degraded under humid conditions. MXene contains various functional groups responsible for good hydrophilicity such as GO membranes. Due to the hydrophilic properties of MXene, it can easily form hydrogen bonding with water molecules that results in degradation and delamination into water. This can possibly be modified by MXenes with a number of materials including polymers, nanoparticles, 2D sheets, and 3D materials. Efforts should be carried out in this direction to improve the stability of membranes by utilizing their functional groups with suitable crosslinking agents. Furthermore, focus should be given to controlled interlayer spacing, shape, size, and atomic defects within MXenes to improve the separation performance.

As for antibacterial studies, only $\mathrm{Ti}_{3} \mathrm{C}_{2} \mathrm{~T}_{\mathrm{x}}$ MXene has been tested against particular types of bacterial strain. More work is needed to use different type of MXenes and pathogens with different concentration. The bactericidal mechanism is still not clear. More theoretical and experimental investigations are required to fully understand the mechanism. Overall, when compared with graphene, MXene is still in an early stage with much more research needed, particularly on water purification, desalination, and antibacterial properties.

Author Contributions: Conceptualization, I.M., F.H.M., A.A.M. and R.A.; writing-original draft preparation, I.M., K.H.T., J.-W.L. and K.H.K.; writing-review and editing, R.A., F.R. and F.S.; supervision, K.H.T., A.A.M. and K.H.C.; project administration, K.H.T., A.A.M. and K.H.C.; funding acquisition, K.H.C. All authors have read and agreed to the published version of the manuscript.

Funding: This work was supported by the National Research Foundation of Korea (NRF) grant funded by the Korea government (MSIT) (NRF-2018R1A2B3001830).

Conflicts of Interest: The authors declare that they have no known competing financial or personal interest that could have an effect on the work reported in this paper.

\section{References}

1. Morris, R.D. Drinking water and cancer. Environ. Health Perspect 1995, 103 (Suppl. S8), 225-231. [CrossRef] [PubMed]

2. Khalid, M.; Manzoor, S.; Ahmad, H.; Asif, A.; Bangash, T.A.; Latif, A.; Jaleel, S. Purinoceptor expression in hepatocellular virus (HCV)-induced and non-HCV hepatocellular carcinoma: An insight into the proviral role of the P2X4 receptor. Mol. Biol. Rep. 2018, 45, 2625-2630. [CrossRef]

3. Asif, A.; Khalid, M.; Manzoor, S.; Ahmad, H.; Rehman, A.U. Role of purinergic receptors in hepatobiliary carcinoma in Pakistani population: An approach towards proinflammatory role of P2X4 and P2X7 receptors. Purinergic Signal. 2019, 15, 367-374. [CrossRef] [PubMed]

4. Hrudey, S.; Payment, P.; Huck, P.; Gillham, R.; Hrudey, E. A fatal waterborne disease epidemic in Walkerton, Ontario: Comparison with other waterborne outbreaks in the developed world. Water Sci. Technol. 2003, 47, 7-14. [CrossRef] [PubMed] 
5. Asif, A.; Manzoor, S.; Tuz-Zahra, F.; Saalim, M.; Ashraf, M.; Ishtiyaq, J.; Khalid, M. Zika virus: Immune evasion mechanisms, currently available therapeutic regimens, and vaccines. Viral Immunol. 2017, 30, 682-690. [CrossRef] [PubMed]

6. Tauxe, R.V.; Mintz, E.D.; Quick, R.E. Epidemic cholera in the new world: Translating field epidemiology into new prevention strategies. Emerg. Infect. Dis. 1995, 1, 141. [CrossRef]

7. Aziz, N.; Hanafiah, M.M. Application of life cycle assessment for desalination: Progress, challenges and future directions. Environ. Pollut. 2021, 268, 115948. [CrossRef] [PubMed]

8. Gude, V.G. Desalination and sustainability-An appraisal and current perspective. Water Res. 2016, 89, 87-106. [CrossRef]

9. Pan, S.Y.; Haddad, A.Z.; Kumar, A.; Wang, S.W. Brackish water desalination using reverse osmosis and capacitive deionization at the water-energy nexus. Water Res. 2020, 183, 116064. [CrossRef]

10. Ahmed, Z.; Rehman, F.; Ali, U.; Ali, A.; Iqbal, M.; Thebo, K.H. Recent Advances in MXene-based Separation Membranes. ChemBioEng Rev. 2021, 8, 110-120. [CrossRef]

11. Ali, A.; Aamir, M.; Thebo, K.H.; Akhtar, J. Laminar Graphene Oxide Membranes Towards Selective Ionic and Molecular Separations: Challenges and Progress. Chem. Rec. 2020, 20, 344-354. [CrossRef] [PubMed]

12. Sharif, S.; Ahmad, K.S.; Rehman, F.; Bhatti, Z.; Thebo, K.H. Two-dimensional graphene oxide based membranes for ionic and molecular separation: Current status and challenges. J. Environ. Chem. Eng. 2021, 9, 105605. [CrossRef]

13. Wang, E.N.; Karnik, R. Water desalination: Graphene cleans up water. Nat. Nano 2012, 7, 552-554. [CrossRef] [PubMed]

14. Ali, Z.; Mehmood, M.; Ahmed, J.; Majeed, A.; Thebo, K.H. CVD grown defect rich-MWCNTs with anchored CoFe alloy nanoparticles for OER activity. Mater. Lett. 2020, 259, 126831. [CrossRef]

15. Ali, Z.; Mehmood, M.; Ahmed, J.; Majeed, A.; Thebo, K.H. MWCNTs and carbon onions grown by CVD method on nickel-cobalt alloy nanocomposites prepared via novel alcogel electrolysis technique and its oxygen evolution reaction application. Mater. Res. Express 2019, 6, 105627. [CrossRef]

16. Fan, H.; Peng, M.; Strauss, I.; Mundstock, A.; Meng, H.; Caro, J. MOF-in-COF molecular sieving membrane for selective hydrogen separation. Nat. Commun. 2021, 12, 38. [CrossRef]

17. Rehman, F.; Thebo, K.H.; Aamir, M.; Akhtar, J. Chapter 8-Nanomembranes for Water Treatment. In Nanotechnology in the Beverage Industry; Amrane, A., Rajendran, S., Nguyen, T.A., Assadi, A.A., Sharoba, A.M., Eds.; Elsevier: Amsterdam, The Netherlands, 2020; pp. 207-240. [CrossRef]

18. Yang, H.; Yang, L.; Wang, H.; Xu, Z.; Zhao, Y.; Luo, Y.; Nasir, N.; Song, Y.; Wu, H.; Pan, F.; et al. Covalent organic framework membranes through a mixed-dimensional assembly for molecular separations. Nat. Commun. 2019, 10, 2101. [CrossRef]

19. Qian, X.; Chen, L.; Yin, L.; Liu, Z.; Pei, S.; Li, F.; Hou, G.; Chen, S.; Song, L.; Thebo, K.H.; et al. CdPS3 nanosheets-based membrane with high proton conductivity enabled by Cd vacancies. Science 2020, 370, 596-600. [CrossRef]

20. Thebo, K.H.; Qian, X.; Zhang, Q.; Chen, L.; Cheng, H.M.; Ren, W. Highly stable graphene-oxide-based membranes with superior permeability. Nat. Commun. 2018, 9, 1486. [CrossRef]

21. Zhang, Q.; Qian, X.; Thebo, K.H.; Cheng, H.-M.; Ren, W. Controlling reduction degree of graphene oxide membranes for improved water permeance. Sci. Bull. 2018, 63, 788-794. [CrossRef]

22. Thebo, K.H.; Qian, X.; Wei, Q.; Zhang, Q.; Cheng, H.-M.; Ren, W. Reduced graphene oxide/metal oxide nanoparticles composite membranes for highly efficient molecular separation. J. Mater. Sci. Technol. 2018, 34, 1481-1486. [CrossRef]

23. Ali, A.; Pothu, R.; Siyal, S.H.; Phulpoto, S.; Sajjad, M.; Thebo, K.H. Graphene-based membranes for $\mathrm{CO}_{2}$ separation. Mater. Sci. Energy Technol. 2019, 2, 83-88. [CrossRef]

24. Jaffri, S.B.; Ahmad, K.S.; Thebo, K.H.; Rehman, F. Recent developments in carbon nanotubes-based perovskite solar cells with boosted efficiency and stability. Z. Phys. Chem. 2021. [CrossRef]

25. Ahmed Janjhi, F.; Chandio, I.; Ali Memon, A.; Ahmed, Z.; Hussain Thebo, K.; Ali Ayaz Pirzado, A.; Ali Hakro, A.; Iqbal, M. Functionalized graphene oxide based membranes for ultrafast molecular separation. Sep. Purif. Technol. 2020, $274,117969$. [CrossRef]

26. Chandio, I.; Janjhi, F.A.; Memon, A.A.; Memon, S.; Ali, Z.; Thebo, K.H.; Pirzado, A.A.A.; Hakro, A.A.; Khan, W.S. Ultrafast ionic and molecular sieving through graphene oxide based composite membranes. Desalination 2020, 500, 114848. [CrossRef]

27. Maqbool, I.; Rehman, F.; Soomro, F.; Bhatti, Z.; Ali, U.; Jatoi, A.H.; Lal, B.; Iqbal, M.; Phulpoto, S.; Ali, A.; et al. Graphene-based Materials for Fighting Coronavirus Disease 2019: Challenges and Opportunities. ChemBioEng Rev. 2021, 8, 67-77. [CrossRef]

28. Chen, C.; Wang, J.; Liu, D.; Yang, C.; Liu, Y.; Ruoff, R.S.; Lei, W. Functionalized boron nitride membranes with ultrafast solvent transport performance for molecular separation. Nat. Commun. 2018, 9, 1902. [CrossRef] [PubMed]

29. Chethikkattuveli Salih, A.R.; Hyun, K.; Asif, A.; Soomro, A.M.; Farooqi, H.M.U.; Kim, Y.S.; Kim, K.H.; Lee, J.W.; Huh, D.; Choi, K.H. Extracellular Matrix Optimization for Enhanced Physiological Relevance in Hepatic Tissue-Chips. Polymers 2021, 13, 3016. [CrossRef]

30. Pendergast, M.M.; Hoek, E.M. A review of water treatment membrane nanotechnologies. Energy Environ. Sci. 2011, 4, $1946-1971$. [CrossRef]

31. Asif, A.; Kim, K.H.; Jabbar, F.; Kim, S.; Choi, K.H. Real-time sensors for live monitoring of disease and drug analysis in microfluidic model of proximal tubule. Microfluid. Nanofluidics 2020, 24, 43. [CrossRef]

32. Asif, A.; Park, S.H.; Soomro, A.M.; Khalid, M.A.U.; Salih, A.R.C.; Kang, B.; Ahmed, F.; Kim, K.H.; Choi, K.H. Microphysiological system with continuous analysis of albumin for hepatotoxicity modeling and drug screening. J. Ind. Eng. Chem. 2021, 98, 318-326. [CrossRef] 
33. Kim, Y.-S.; Asif, A.; Chethikkattuveli Salih, A.R.; Lee, J.-W.; Hyun, K.-N.; Choi, K.-H. Gravity-Based Flow Efficient Perfusion Culture System for Spheroids Mimicking Liver Inflammation. Biomedicines 2021, 9, 1369. [CrossRef] [PubMed]

34. Salih, A.R.C.; Farooqi, H.M.U.; Kim, Y.S.; Lee, S.H.; Choi, K.H. Impact of serum concentration in cell culture media on tight junction proteins within a multiorgan microphysiological system. Microelectron. Eng. 2020, 232, 111405. [CrossRef]

35. Waqas, M.; Manzoor Soomro, A.; Ali, S.; Kumar, S.; Chan, S.; Hussain, K.; Hussain Memon, F.; Ahmed Shaikh, S. Multifunctional Cathodic Interlayer with Polysulfide Immobilization Mechanism for High-Performance Li-S Batteries. ChemistrySelect 2020, 5, 12009-12019. [CrossRef]

36. Soomro, A.M.; Memon, F.H.; Lee, J.-W.; Ahmed, F.; Kim, K.H.; Kim, Y.S.; Choi, K.H. Fully 3D printed multi-material soft bio-inspired frog for underwater synchronous swimming. Int. J. Mech. Sci. 2021, 210, 106725. [CrossRef]

37. Caro, J. Hierarchy in inorganic membranes. Chem. Soc. Rev. 2016, 45, 3468-3478. [CrossRef]

38. Yang, B.; Tang, P.-F.; Liu, C.-J.; Li, R.; Li, X.-D.; Chen, J.; Qiao, Z.-Q.; Zhang, H.-P.; Yang, G.-C. An efficient light-to-heat conversion coupling photothermal effect and exothermic chemical reaction in Au NRs/V2C MXene membranes for high-performance laser ignition. Def. Technol. 2021. Advance online publication. [CrossRef]

39. Shi, F.; Sun, J.; Wang, J.; Liu, M.; Yan, Z.; Zhu, B.; Li, Y.; Cao, X. MXene versus graphene oxide: Investigation on the effects of 2D nanosheets in mixed matrix membranes for CO2 separation. J. Membr. Sci. 2021, 620, 118850. [CrossRef]

40. Tong, X.; Liu, S.; Qu, D.; Gao, H.; Yan, L.; Chen, Y.; Crittenden, J. Tannic acid-metal complex modified MXene membrane for contaminants removal from water. J. Membr. Sci. 2021, 622, 119042. [CrossRef]

41. Chen, R.; Cheng, Y.; Wang, P.; Wang, Y.; Wang, Q.; Yang, Z.; Tang, C.; Xiang, S.; Luo, S.; Huang, S.; et al. Facile synthesis of a sandwiched Ti3C2Tx MXene/nZVI/fungal hypha nanofiber hybrid membrane for enhanced removal of Be(II) from Be(NH2)2 complexing solutions. Chem. Eng. J. 2021, 421, 129682. [CrossRef]

42. Ajibade, T.F.; Tian, H.; Hassan Lasisi, K.; Xue, Q.; Yao, W.; Zhang, K. Multifunctional PAN UF membrane modified with 3D-MXene/O-MWCNT nanostructures for the removal of complex oil and dyes from industrial wastewater. Sep. Purif. Technol. 2021, 275, 119135. [CrossRef]

43. Zhu, X.; Zhang, X.; Li, J.; Luo, X.; Xu, D.; Wu, D.; Wang, W.; Cheng, X.; Li, G.; Liang, H. Crumple-textured polyamide membranes via MXene nanosheet-regulated interfacial polymerization for enhanced nanofiltration performance. J. Membr. Sci. 2021, 635, 119536. [CrossRef]

44. Sun, Y.; Xu, D.; Li, S.; Cui, L.; Zhuang, Y.; Xing, W.; Jing, W. Assembly of multidimensional MXene-carbon nanotube ultrathin membranes with an enhanced anti-swelling property for water purification. J. Membr. Sci. 2021, 623, 119075. [CrossRef]

45. Zeng, G.; Wei, K.; Zhang, H.; Zhang, J.; Lin, Q.; Cheng, X.; Sengupta, A.; Chiao, Y.-H. Ultra-high oil-water separation membrane based on two-dimensional MXene(Ti3C2Tx) by co-incorporation of halloysite nanotubes and polydopamine. Appl. Clay Sci. 2021, 211, 106177. [CrossRef]

46. Lin, Q.; Liu, Y.; Zeng, G.; Li, X.; Wang, B.; Cheng, X.; Sengupta, A.; Yang, X.; Feng, Z. Bionics inspired modified two-dimensional MXene composite membrane for high-throughput dye separation. J. Environ. Chem. Eng. 2021, 9, 105711. [CrossRef]

47. Jin, Y.; Fan, Y.; Meng, X.; Li, J.; Li, C.; Sunarso, J.; Yang, N.; Meng, B.; Zhang, W. Modeling of hydrated cations transport through 2D MXene $\left(\mathrm{Ti}_{3} \mathrm{C}_{2} \mathrm{~T}_{\mathrm{x}}\right)$ membranes for water purification. J. Membr. Sci. 2021, 631, 119346. [CrossRef]

48. Huang, Z.; Liu, J.; Liu, Y.; Xu, Y.; Li, R.; Hong, H.; Shen, L.; Lin, H.; Liao, B.-Q. Enhanced permeability and antifouling performance of polyether sulfone (PES) membrane via elevating magnetic Ni@MXene nanoparticles to upper layer in phase inversion process J. Membr. Sci. 2021, 623, 119080. [CrossRef]

49. Li, S.; Geng, X.; Ma, C.; Zhan, X.; Li, J.; Ma, M.; He, J.; Wang, L. Improved performance of three-component structure mixed membrane for pervaporation modified by lignosulfonates@2D-MXene. Sep. Purif. Technol. 2021, 276, 119294. [CrossRef]

50. Long, Q.; Zhao, S.; Chen, J.; Zhang, Z.; Qi, G.; Liu, Z.-Q. Self-assembly enabled nano-intercalation for stable high-performance MXene membranes. J. Membr. Sci. 2021, 635, 119464. [CrossRef]

51. Meng, B.; Liu, G.; Mao, Y.; Liang, F.; Liu, G.; Jin, W. Fabrication of surface-charged MXene membrane and its application for water desalination. J. Membr. Sci. 2021, 623, 119076. [CrossRef]

52. Hu, J.; Zhan, Y.; Zhang, G.; Feng, Q.; Yang, W.; Chiao, Y.-H.; Zhang, S.; Sun, A. Durable and super-hydrophilic/underwater super-oleophobic two-dimensional MXene composite lamellar membrane with photocatalytic self-cleaning property for efficient oil/water separation in harsh environments. J. Membr. Sci. 2021, 637, 119627. [CrossRef]

53. Jaffari, Z.H.; Abuabdou, S.M.A.; Ng, D.-Q.; Bashir, M.J.K. Insight into two-dimensional MXenes for environmental applications: Recent progress, challenges, and prospects. FlatChem 2021, 28, 100256. [CrossRef]

54. Fu, Y.; Zhang, J.; Lin, H.; Mo, A. 2D titanium carbide(MXene) nanosheets and 1D hydroxyapatite nanowires into free standing nanocomposite membrane: In vitro and in vivo evaluations for bone regeneration. Mater. Sci. Eng. C 2021, 118, 111367. [CrossRef] [PubMed]

55. Lao, J.; Lv, R.; Gao, J.; Wang, A.; Wu, J. Aqueous Stable Ti(3)C(2) MXene Membrane with Fast and Photoswitchable Nanofluidic Transport. ACS Nano 2018, 12, 12464-12471. [CrossRef]

56. Fei, M.; Lin, R.; Deng, Y.; Xian, H.; Bian, R.; Zhang, X.; Cheng, J.; Xu, C.; Cai, D. Polybenzimidazole/Mxene composite membranes for intermediate temperature polymer electrolyte membrane fuel cells. Nanotechnology 2018, 29, 035403. [CrossRef]

57. Liu, G.; Cheng, L.; Chen, G.; Liang, F.; Liu, G.; Jin, W. Pebax-Based Membrane Filled with Two-Dimensional Mxene Nanosheets for Efficient $\mathrm{CO}(2)$ Capture. Chem. Asian J. 2020, 15, 2364-2370. [CrossRef] 
58. Rezakazemi, M.; Arabi Shamsabadi, A.; Lin, H.; Luis, P.; Ramakrishna, S.; Aminabhavi, T.M. Sustainable MXenes-based membranes for highly energy-efficient separations. Renew. Sustain. Energy Rev. 2021, 143, 110878. [CrossRef]

59. Al-Hamadani, Y.A.J.; Jun, B.-M.; Yoon, M.; Taheri-Qazvini, N.; Snyder, S.A.; Jang, M.; Heo, J.; Yoon, Y. Applications of MXenebased membranes in water purification: A review. Chemosphere 2020, 254, 126821. [CrossRef]

60. Feng, X.; Yu, Z.; Sun, Y.; Long, R.; Shan, M.; Li, X.; Liu, Y.; Liu, J. Review MXenes as a new type of nanomaterial for environmental applications in the photocatalytic degradation of water pollutants. Ceram. Int. 2021, 47, 7321-7343. [CrossRef]

61. Rasool, K.; Pandey, R.P.; Rasheed, P.A.; Buczek, S.; Gogotsi, Y.; Mahmoud, K.A. Water treatment and environmental remediation applications of two-dimensional metal carbides (MXenes). Mater. Today 2019, 30, 80-102. [CrossRef]

62. Hwang, S.K.; Kang, S.-M.; Rethinasabapathy, M.; Roh, C.; Huh, Y.S. MXene: An emerging two-dimensional layered material for removal of radioactive pollutants. Chem. Eng. J. 2020, 397, 125428. [CrossRef]

63. Ren, C.E.; Hatzell, K.B.; Alhabeb, M.; Ling, Z.; Mahmoud, K.A.; Gogotsi, Y. Charge- and Size-Selective Ion Sieving Through Ti3C2Tx MXene Membranes. J. Phys. Chem. Lett. 2015, 6, 4026-4031. [CrossRef] [PubMed]

64. Ding, L.; Wei, Y.; Wang, Y.; Chen, H.; Caro, J.; Wang, H. A Two-Dimensional Lamellar Membrane: MXene Nanosheet Stacks. Angew. Chem. Int. Ed. 2017, 56, 1825-1829. [CrossRef]

65. Kang, K.M.; Kim, D.W.; Ren, C.E.; Cho, K.M.; Kim, S.J.; Choi, J.H.; Nam, Y.T.; Gogotsi, Y.; Jung, H.-T. Selective Molecular Separation on Ti3C2Tx-Graphene Oxide Membranes during Pressure-Driven Filtration: Comparison with Graphene Oxide and MXenes. ACS Appl. Mater. Interfaces 2017, 9, 44687-44694. [CrossRef]

66. Liu, T.; Liu, X.; Graham, N.; Yu, W.; Sun, K. Two-dimensional MXene incorporated graphene oxide composite membrane with enhanced water purification performance. J. Membr. Sci. 2020, 593, 117431. [CrossRef]

67. Wang, J.; Zhang, Z.; Zhu, J.; Tian, M.; Zheng, S.; Wang, F.; Wang, X.; Wang, L. Ion sieving by a two-dimensional Ti3C2Tx alginate lamellar membrane with stable interlayer spacing. Nat. Commun. 2020, 11, 3540. [CrossRef] [PubMed]

68. Wang, C.; Cheng, R.; Hou, P.-X.; Ma, Y.; Majeed, A.; Wang, X.; Liu, C. MXene-Carbon Nanotube Hybrid Membrane for Robust Recovery of Au from Trace-Level Solution. ACS Appl. Mater. Interfaces 2020, 12, 43032-43041. [CrossRef] [PubMed]

69. Tian, W.; VahidMohammadi, A.; Wang, Z.; Ouyang, L.; Beidaghi, M.; Hamedi, M.M. Layer-by-layer self-assembly of pillared two-dimensional multilayers. Nat. Commun. 2019, 10, 2558. [CrossRef]

70. Hong, W.; Wyatt, B.C.; Nemani, S.K.; Anasori, B. Double transition-metal MXenes: Atomistic design of two-dimensional carbides and nitrides. MRS Bull. 2020, 45, 850-861. [CrossRef]

71. Xu, D.; Zhu, X. MXene Nanosheet Templated Nanofiltration Membranes toward Ultrahigh Water Transport. Environ. Sci. Technoogies 2021, 55, 1270-1278. [CrossRef]

72. Karahan, H.E.; Goh, K. MXene Materials for Designing Advanced Separation Membranes. Adv. Mater. 2020, 32 , e1906697. [CrossRef] [PubMed]

73. Han, R.; Ma, X.; Xie, Y.; Teng, D.; Zhang, S. Preparation of a new 2D MXene/PES composite membrane with excellent hydrophilicity and high flux. RSC Adv. 2017, 7, 56204-56210. [CrossRef]

74. Cheng, Y.; Pu, Y.; Zhao, D. Two-Dimensional Membranes: New Paradigms for High-Performance Separation Membranes. Chem. Asian J. 2020, 15, 2241-2270. [CrossRef] [PubMed]

75. Zhang, H.; Wang, Z.; Shen, Y.; Mu, P.; Wang, Q.; Li, J. Ultrathin 2D Ti(3)C(2)T(x) MXene membrane for effective separation of oil-in-water emulsions in acidic, alkaline, and salty environment. J. Colloid Interface Sci. 2020, 561, 861-869. [CrossRef]

76. Shen, Z.; Chen, W.; Xu, H.; Yang, W.; Kong, Q.; Wang, A.; Ding, M.; Shang, J. Fabrication of a Novel Antifouling Polysulfone Membrane with in Situ Embedment of Mxene Nanosheets. Int. J. Environ. Res. Public Health 2019, 16, 4659. [CrossRef] [PubMed]

77. Zha, X.J.; Zhao, X.; Pu, J.H.; Tang, L.S.; Ke, K.; Bao, R.Y.; Bai, L.; Liu, Z.Y.; Yang, M.B. Flexible Anti-Biofouling MXene/Cellulose Fibrous Membrane for Sustainable Solar-Driven Water Purification. ACS Appl. Mater. Interfaces 2019, 11, 36589-36597. [CrossRef]

78. Wu, X.; Ding, M.; Xu, H. Scalable Ti(3)C(2)T(x) MXene Interlayered Forward Osmosis Membranes for Enhanced Water Purification and Organic Solvent Recovery. ACS Nano 2020, 14, 9125-9135. [CrossRef]

79. Kim, S.; Yu, M. Fouling and Retention Mechanisms of Selected Cationic and Anionic Dyes in a Ti(3)C(2)T(x) MXene-Ultrafiltration Hybrid System. ACS Appl. Mater. Interfaces 2020, 12, 16557-16565. [CrossRef]

80. Hong, S. Two-Dimensional Ti(3)C(2)T(x) MXene Membranes as Nanofluidic Osmotic Power Generators. ACS Nano 2019, 13, 8917-8925. [CrossRef]

81. Mojtabavi, M.; VahidMohammadi, A. Single-Molecule Sensing Using Nanopores in Two-Dimensional Transition Metal Carbide (MXene) Membranes. ACS Nano 2019, 13, 3042-3053. [CrossRef]

82. Liu, G.; Shen, J.; Liu, Q.; Liu, G.; Xiong, J.; Yang, J.; Jin, W. Ultrathin two-dimensional MXene membrane for pervaporation desalination. J. Membr. Sci. 2018, 548, 548-558. [CrossRef]

83. Pandey, R.P.; Rasool, K.; Madhavan, V.E.; Aïssa, B.; Gogotsi, Y.; Mahmoud, K.A. Ultrahigh-flux and fouling-resistant membranes based on layered silver/MXene $\left(\mathrm{Ti}_{3} \mathrm{C}_{2} \mathrm{~T}_{\mathrm{x}}\right)$ nanosheets. J. Mater. Chem. A 2018, 6, 3522-3533. [CrossRef]

84. Lu, Z.; Wei, Y.; Deng, J.; Ding, L.; Li, Z.-K.; Wang, H. Self-Crosslinked MXene $\left(\mathrm{Ti}_{3} \mathrm{C}_{2} \mathrm{~T}_{\mathrm{x}}\right)$ Membranes with Good Antiswelling Property for Monovalent Metal Ion Exclusion. ACS Nano 2019, 13, 10535-10544. [CrossRef] [PubMed]

85. Ding, L.; Li, L.; Liu, Y.; Wu, Y.; Lu, Z.; Deng, J.; Wei, Y.; Caro, J.; Wang, H. Effective ion sieving with Ti3C2Tx MXene membranes for production of drinking water from seawater. Nat. Sustain. 2020, 3, 296-302. [CrossRef]

86. Wang, Y.; Li, L.; Wei, Y.; Xue, J.; Chen, H.; Ding, L.; Caro, J.; Wang, H. Water Transport with Ultralow Friction through Partially Exfoliated g-C3N4 Nanosheet Membranes with Self-Supporting Spacers. Angew. Chem. Int. Ed. 2017, 56, 8974-8980. [CrossRef] 
87. Gao, L.; Li, C.; Huang, W.; Mei, S.; Lin, H.; Qu, Q.; Zhang, Y.; Guo, J.; Zhang, F.; Xu, S.; et al. MXene/Polymer Membranes: Synthesis, Properties, and Emerging Applications. Chem. Mater. 2020, 32, 1703-1747. [CrossRef]

88. Han, R.; Xie, Y.; Ma, X. Crosslinked P84 copolyimide/MXene mixed matrix membrane with excellent solvent resistance and permselectivity. Chin. J. Chem. Eng. 2019, 27, 877-883. [CrossRef]

89. Fahimirad, S.; Fahimirad, Z.; Sillanpää, M. Efficient removal of water bacteria and viruses using electrospun nanofibers. Sci. Total Environ. 2021, 751, 141673. [CrossRef]

90. Rasool, K.; Mahmoud, K.A.; Johnson, D.J.; Helal, M.; Berdiyorov, G.R.; Gogotsi, Y. Efficient Antibacterial Membrane based on Two-Dimensional Ti3C2Tx (MXene) Nanosheets. Sci. Rep. 2017, 7, 1598. [CrossRef]

91. Mayerberger, E.A.; Street, R.M.; McDaniel, R.M.; Barsoum, M.W.; Schauer, C.L. Antibacterial properties of electrospun Ti3C2Tz (MXene)/chitosan nanofibers. RSC Adv. 2018, 8, 35386-35394. [CrossRef]

92. Rozmysłowska-Wojciechowska, A.; Karwowska, E.; Poźniak, S.; Wojciechowski, T.; Chlubny, L.; Olszyna, A.; Ziemkowska, W.; Jastrzebska, A.M. Influence of modification of Ti3C2 MXene with ceramic oxide and noble metal nanoparticles on its antimicrobial properties and ecotoxicity towards selected algae and higher plants. RSC Adv. 2019, 9, 4092-4105. [CrossRef]

93. Huang, K.; Li, Z.; Lin, J.; Han, G.; Huang, P. Two-dimensional transition metal carbides and nitrides (MXenes) for biomedical applications. Chem. Soc. Rev. 2018, 47, 5109-5124. [CrossRef] [PubMed]

94. Zhu, X.; Zhu, Y.; Jia, K.; Abraha, B.S.; Li, Y.; Peng, W.; Zhang, F.; Fan, X.; Zhang, L. A near-infrared light-mediated antimicrobial based on $\mathrm{Ag} / \mathrm{Ti}_{3} \mathrm{C}_{2} \mathrm{~T}_{\mathrm{x}}$ for effective synergetic antibacterial applications. Nanoscale 2020, 12, 19129-19141. [CrossRef]

95. Li, J.; Li, Z.; Liu, X.; Li, C.; Zheng, Y.; Yeung, K.W.K.; Cui, Z.; Liang, Y.; Zhu, S.; Hu, W.; et al. Interfacial engineering of Bi2S3/Ti3C2Tx MXene based on work function for rapid photo-excited bacteria-killing. Nat. Commun. 2021, 12, 1224. [CrossRef] [PubMed]

96. Rasool, K.; Helal, M.; Ali, A.; Ren, C.E.; Gogotsi, Y.; Mahmoud, K.A. Antibacterial Activity of $\mathrm{Ti}_{3} \mathrm{C}_{2} \mathrm{~T}_{\mathrm{x}} \mathrm{MXene.} \mathrm{ACS} \mathrm{Nano} \mathrm{2016,} \mathrm{10,}$ 3674-3684. [CrossRef]

97. Zheng, K.; Li, S.; Jing, L.; Chen, P.Y.; Xie, J. Synergistic Antimicrobial Titanium Carbide (MXene) Conjugated with Gold Nanoclusters. Adv. Healthc. Mater. 2020, 9, e2001007. [CrossRef]

98. Jastrzębska, A.M.; Karwowska, E.; Wojciechowski, T.; Ziemkowska, W.; Rozmysłowska, A.; Chlubny, L.; Olszyna, A. The Atomic Structure of $\mathrm{Ti}_{2} \mathrm{C}$ and $\mathrm{Ti}_{3} \mathrm{C}_{2}$ MXenes is Responsible for Their Antibacterial Activity Toward E. coli Bacteria. J. Mater. Eng. Perform. 2019, 28, 1272-1277. [CrossRef]

99. Zhang, T.; Zhang, L.-Z. Development of a MXene-based membrane with excellent anti-fouling for air humidification dehumidification type desalination. J. Membr. Sci. 2022, 641, 119907. [CrossRef]

100. Sun, Y.; Li, S.; Zhuang, Y.; Liu, G.; Xing, W.; Jing, W. Adjustable interlayer spacing of ultrathin MXene-derived membranes for ion rejection. J. Membr. Sci. 2019, 591, 117350. [CrossRef]

101. Han, R.; Wu, P. High-performance graphene oxide nanofiltration membrane with continuous nanochannels prepared by the in situ oxidation of MXene. J. Mater. Chem. A 2019, 7, 6475-6481. [CrossRef]

102. Xu, Z.; Sun, Y.; Zhuang, Y.; Jing, W.; Ye, H.; Cui, Z. Assembly of 2D MXene nanosheets and TiO2 nanoparticles for fabricating mesoporous TiO2-MXene membranes. J. Membr. Sci. 2018, 564, 35-43. [CrossRef]

103. Wei, S.; Xie, Y.; Xing, Y.; Wang, L.; Ye, H.; Xiong, X.; Wang, S.; Han, K. Two-dimensional graphene Oxide/MXene composite lamellar membranes for efficient solvent permeation and molecular separation. J. Membr. Sci. 2019, 582, 414-422. [CrossRef]

104. Xue, Q.; Zhang, K. MXene nanocomposite nanofiltration membrane for low carbon and long-lasting desalination. J. Membr. Sci. 2021, 640, 119808. [CrossRef]

105. Tan, Y.Z.; Wang, H.; Han, L.; Tanis-Kanbur, M.B.; Pranav, M.V.; Chew, J.W. Photothermal-enhanced and fouling-resistant membrane for solar-assisted membrane distillation. J. Membr. Sci. 2018, 565, 254-265. [CrossRef] 